\title{
Algal supplement enhancement of static and recirculating system culture of Macrobracbium rosenbergii larvae*
}

\author{
J. J. MAnZI ${ }^{1} \&$ M. B. MADDox ${ }^{2}$ \\ ${ }^{1}$ Marine Resources Research Institute, \\ South Carolina Wildlife and Marine Resources Department; \\ Charleston, South Carolina, USA, \\ and \\ ${ }^{2}$ Department of Biology, College of Charleston; \\ Charleston, South Carolina, USA
}

\begin{abstract}
KURZFASSUNG: Verbesserung stehender und rezirkulierender Kultursysteme von Macrobracbium rosenbergii-Larven durch Algenzusatz. Im Rahmen eines Aquakulturvorhabens wurde geprüft, inwieweit sich die Gegenwart der Diatomee Phaeodactylum tricornutum auf die Zucht der Garnele Macrobrachium rosenbergii (DE MAN) auswirkt. Als Nahrung für die Larven von M. rosenbergii dienten in den Versuchsreihen $\left(12 \% \mathrm{~S}, 28 \pm 1^{\circ} \mathrm{C}\right.$, Dauerlicht) Nauplien von Artemia salina und ab 9. Lebenstag zusätzliche Gaben von Mugil-Rogen. Verglichen mit den Kontrollreihen bewirkte die Gegenwart der Diatomeen ( $340000 \mathrm{Zellen} / \mathrm{ml}$ ) eine signifikant erhöhte Uberlebensrate der Larven, und zwar sowohl in stehenden als auch in rezirkulierenden Kultureinheiten. Zudem erreichte eine größere Anzahl von Individuen das Postlarvalstadium, wobei auch die Metamorphose früher als bei den algenfrei gezüchteten Kontrolltieren einsetzte. Wasserchemische Untersuchungen zeigten, daß die verbesserten Zuchterfolge nicht von den gemessenen Konzentrationen der Endprodukte des Stickstoff wechsels $\left(\mathrm{NH}_{4}^{+}, \mathrm{NO}_{2}^{-}, \mathrm{NO}_{3}{ }^{-}\right) \mathrm{ab}^{-}$ hängig waren.
\end{abstract}

\section{INTRODUCTION}

Interest in the culture of the giant prawn, Macrobracbium rosenbergii (DE MAN), has increased substantially since LING (1962) first demonstrated successful rearing techniques for larvae and juveniles. Widespread investigations of prawn culture have increased not only our knowledge of the biology of this crustacean but also the effi-

* This work (Contribution No. 65 South Carolina Marine Resources Center and contribution No. 43 Grice Marine Biological Laboratory) is a result of research supported by NOAA Office of Sea Grant Department of Commerce, under grants \# 04-5-158-5 and \# 04-6-15844009. The U.S. Government is authorized to produce and distribute reprints for governmental purposes notwithstanding any copyright which may appear hereon. Reference to trade names in this paper does not imply endorsement by NOAA Office of Sea Grant or the State of South Carolina. 
ciency and standardization of culture operations (Ling, 1969a; Fujnura \& OKamoto, 1970; SANDIFER \& SMITH, 1974). Recent reports have indicated that relatively high larval survival and postlarval production can be accomplished routinely (FujImura, 1974; SANDIFER \& SMTTH, in press).

The use of algae in prawn larval culture has been stressed by Fujumura (1966) and Fujimura \& Oкамото (1972). They reported that cultures supplemented with "green water", a dense mixture of phytoplankton and zooplankton, normally result in an increase in larval survival and a decrease in the length of time to stockable postlarvae. WICKINs (1972) reported that unialgal culture also appears to augment the efficiency of larval culture. In experiments testing three algal species, he found that two species, Isochrysis galbana and Tetraselmis suecica, increased growth and survival of larvae when used in combination with Artemia salina nauplii. A recent study by MADDOX \& MANZI (in press) strongly indicated that unialgal supplements enhance the culture of $M$. rosenbergii larvae. They evaluated seven algal species commonly used in mariculture operations and found all supplements increased survival of larvae and production of postlarvae and decreased the length of time to metamorphosis. Of the algal species tested, the Chrysophytes, particularly the diatom Pbaeodactylum tricornutum, appeared to be the most valuable supplements. These treatments routinely resulted in approximately $30 \%$ greater overall survival and between 40 and $50 \%$ more postlarvae than control treatments. The study by MadDox \& ManzI (in press) was performed entirely in static culture using a synthetic seawater formulation (Instant Ocean; Aquarium Systems, Inc.) in semi-weekly water changes. Although static system culture allows the investigator to easily maintain high food densities its cost, both in labor and sea salts, may make it prohibitive on a commercial scale. In order to determine if the algal enhancement of larval culture in static systems is translated to recirculating systems an additional experiment with algal supplements was performed as part of an interdisciplinary program in the development of Macrobrachium aquaculture in South Carolina. The primary objective of this study was to evaluate the effect of algal additions in the culture of Macrobracbium rosenbergii larvae in a recirculating synthetic seawater system.

\section{MATERIALS AND METHODS}

Phaeodactylum tricornutum was suggested as the best algal supplement tested in static system culture (MADDOX \& MANzI, in press). This species was reared from unispecific algal cultures, maintained in $15 \mathrm{ml}$ culture tubes at $19^{\circ} \mathrm{C}$ and a 14 hour/ 10 hour light-dark cycle at the Marine Resources Research Institute's (MRRI) algal culture facility. Tube cultures, 4-7 days old, were used to start $150 \mathrm{ml}$ cultures which were used to inoculate 2.21 Fernbach cultures. Fernbach cultures were then used as inocula for 151 carboy cultures. All cultures were reared in sterile natural brackish water $\left(\sim 20 \%\right.$ enriched with $\mathrm{N}_{2} \mathrm{M}$ (Dupuy, 1973) and a vitamin mix. Cell densities in all cultures were monitored by quadruplicate hemocytometer counts. A quantity of algal culture sufficient to produce an average of 340,000 cells $/ \mathrm{ml}$ was added daily to each larval culture except controls. 
Apart from the addition of algal supplements in the experimental treatments all larval cultures were maintained following standard rearing techniques for $M$. rosenbergii larvae (Fujimura, 1966; Ling, 1969a; 1969b; Fujimura \& Окамото, 1970; Wickins \& BEARd, 1973) as modified at the MRRI (SANDIFER \& SMITH, 1974; SMrTH et al., in press). Larvae were reared in $60 \mathrm{I}$ black fiberglass rounded bottom tanks at a volume of 501 and a stocking density of 75 larvae/l. The tanks were arranged five to a table in a controlled environment room supplied with constant light and aeration and maintained at $28 \pm 1^{\circ} \mathrm{C}$. Submersed gravel filters were used to recirculate water to three tanks on each table (Fig. 1). With this design three tanks were run off a single filter and served as control replicates, three tanks were run off a second filter and served as experimental (algal supplemented) replicates, and three of the remaining four tanks were used as static system experimental replicates. Thus, the experimental design consisted of three treatments: a recirculating control, a recirculating algal supplemented treatment, and a static algal supplemented treatment, each represented by three replicate cultures.

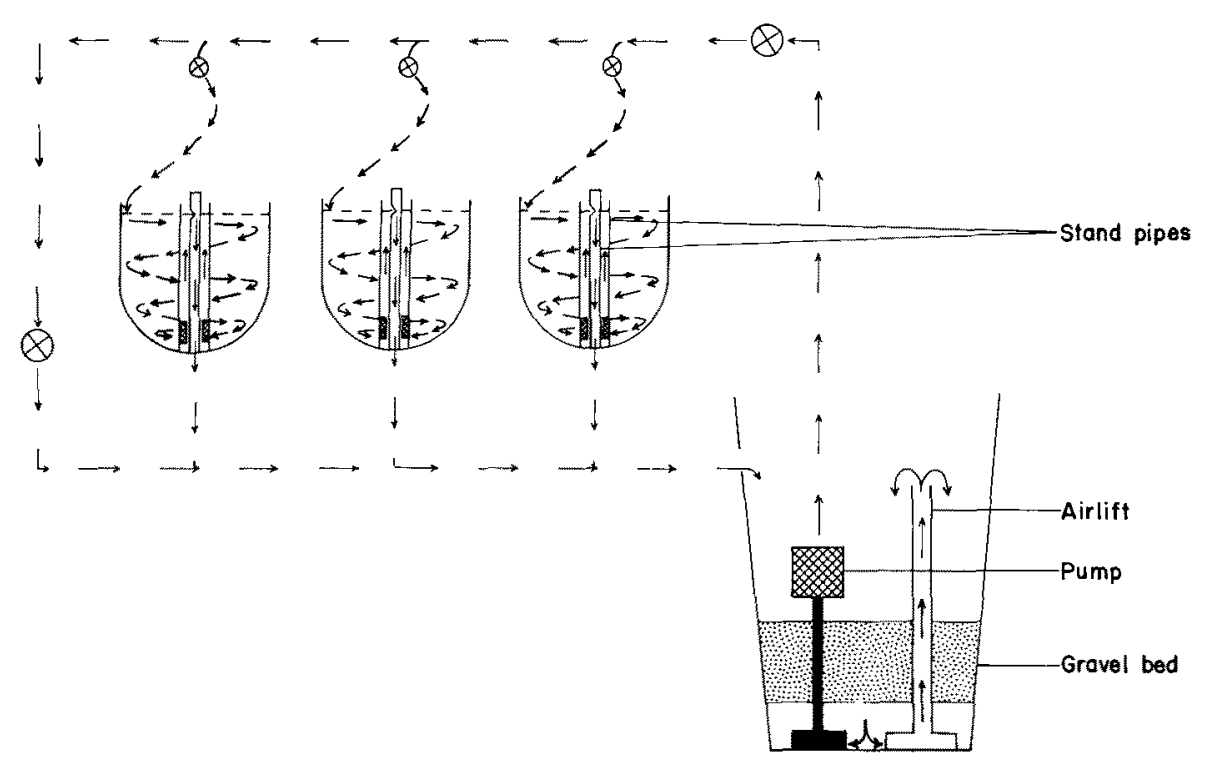

Fig. 1: Schematic showing submersed gravel filter and recirculating system used to evaluate algal supplements in the culture of Macrobrachium rosenbergii larvae

The filters were constructed in 1701 rectangular plastic containers. Approximately $0.028 \mathrm{~m}^{3}$ of dolomite gravel $(3.0-5.0 \mathrm{~mm}$ diameter) was spread over plastic screens forming an $18 \mathrm{~cm}$ layer $13 \mathrm{~cm}$ above the container bottom (Fig. 1). Water was continuously filtered by circulation through an airlift standpipe (Fig. 1). The filters were activated with additions of ammonium chloride using the method described by SRNA (1975). Once daily water was circulated through the culture tanks at the rate of approximately $21 /$ minute by a $1 / 20 \mathrm{hp}$ submersible pump (model no. LC-3C-MD; 
March Manufacturing Co.). Recirculation was continued each day for a period of time sufficient for 3-4 tank water turnovers. Synthetic seawater (Instant Ocean; Aquarium Systems, Inc.) was used exclusively in the larval culture and was changed three times weekly in the static cultures. All tanks were emptied, cleaned, and scalded once a week.

Nauplii of Artemia salina (San Francisco Bay Brand, Newark, California) were used as the primary ration during all stages of larval culture. Cysts were hydrated under constant aeration and light in 151 plastic tanks at $28 \pm 1^{\circ} \mathrm{C}$ and $25 \%$ s using standard rearing techniques (Sorgeloos, 1973; Persoone \& Sorgeloos, 1974, 1975). Nauplii were harvested 20 to 24 hours after cyst immersion and fed to the $M$. rosenbergii larvae at a concentration of 10 nauplii $/ \mathrm{ml}$. Nauplii were added daily to all cultures immediately after each recirculation. After day 9 of the culture this primary ration was supplemented with an average of $1.25 \mathrm{cc}$ of $M u g i l$ sp. roe fed twice daily to each tank.

Evaluation of the algal supplement was determined by estimates of larval growth and periodic counts of larvae and postlarvae. Growth was measured by a larval stage index (LSI) based on the 11 stages described by UNO \& KWON CHIN soo (1969). This index is a measure of central tendency calculated by a weighted average method (i.e. the numbers of larvae at each stage were multiplied by the stage number and the sum of the products was divided by the total number of larvae sampled). Since the LSI is based on an open ended scale (postlarvae are not included) it is necessarily biased toward values below 10 . Thus almost all larvae have to be stage 10 or 11 to derive high index values $(9-11)$. Survival was determined by actual counts at the initiation and days $16,23,28$, and 34 of the culture.

Total ammonia, nitrite, nitrate, and $\mathrm{pH}$ were monitored daily for the first nine days, then ammonia daily for one week (days 16 through 23) using LaMotte Chemical Products Company (Chestertown, Maryland) marine aquarium test kits. The recirculating treatment tanks as well as the filters were sampled immediately before the recirculating/filter periods. The static tanks were also sampled before water exchange.

\section{RESULTS AND DISCUSSION}

Larval stage advancement was similar in all cultures through day 7 (Fig. 2). At this point (LSI $=4.4$ ) algal supplemented cultures began to deviate from controls. Subsequently algal treatments showed comparatively more rapid stage advancement. Both algal supplemented treatments (recirculated and static) indicated similar larval growth rates with stage 10 (LSI) occurring 4 to 5 days respectively, before controls. Initial postlarval observations are also included on Figure 2 and show that postlarvae were first observed in the static algal supplemented cultures (day 18), next in the recirculating algal supplemented cultures (day 21), and last in the controls (day 23). These results on larval growth followed closely the results of previous experiments by the authors (MADDOX \& MANZI, in press); however, this experiment did show slightly more rapid growth and earlier initial postlarvae observations in all treatments.

Survival in all treatments was assessed by actual counts of larvae and postlarvae 


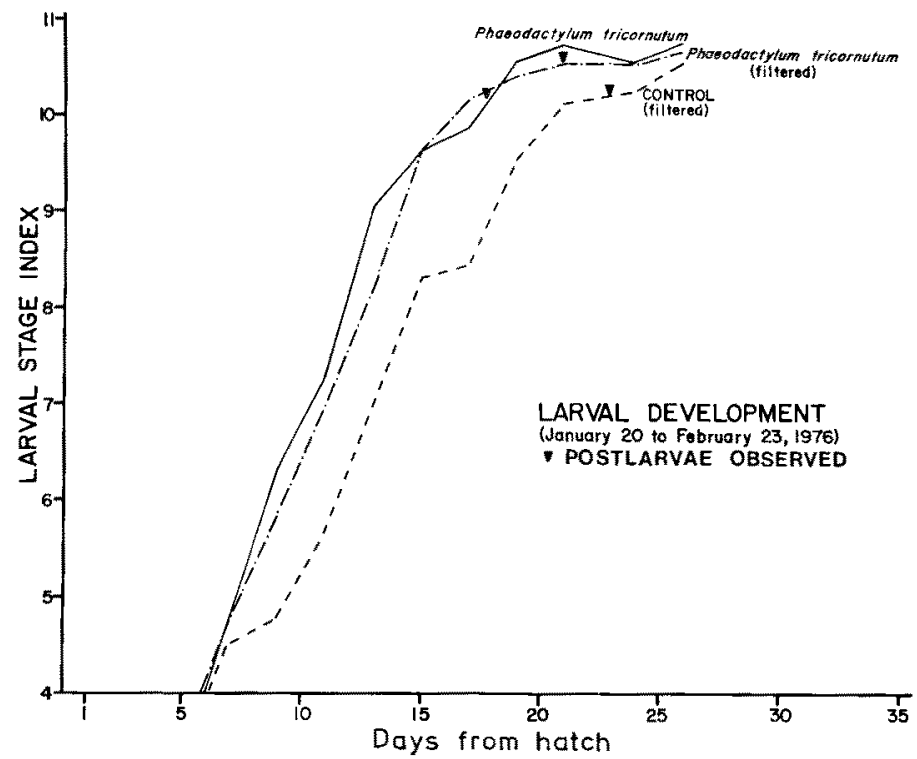

Fig. 2: Rate of Macrobrachium rosenbergii larval development in algal and control treatments (see text for explanation of LSI)

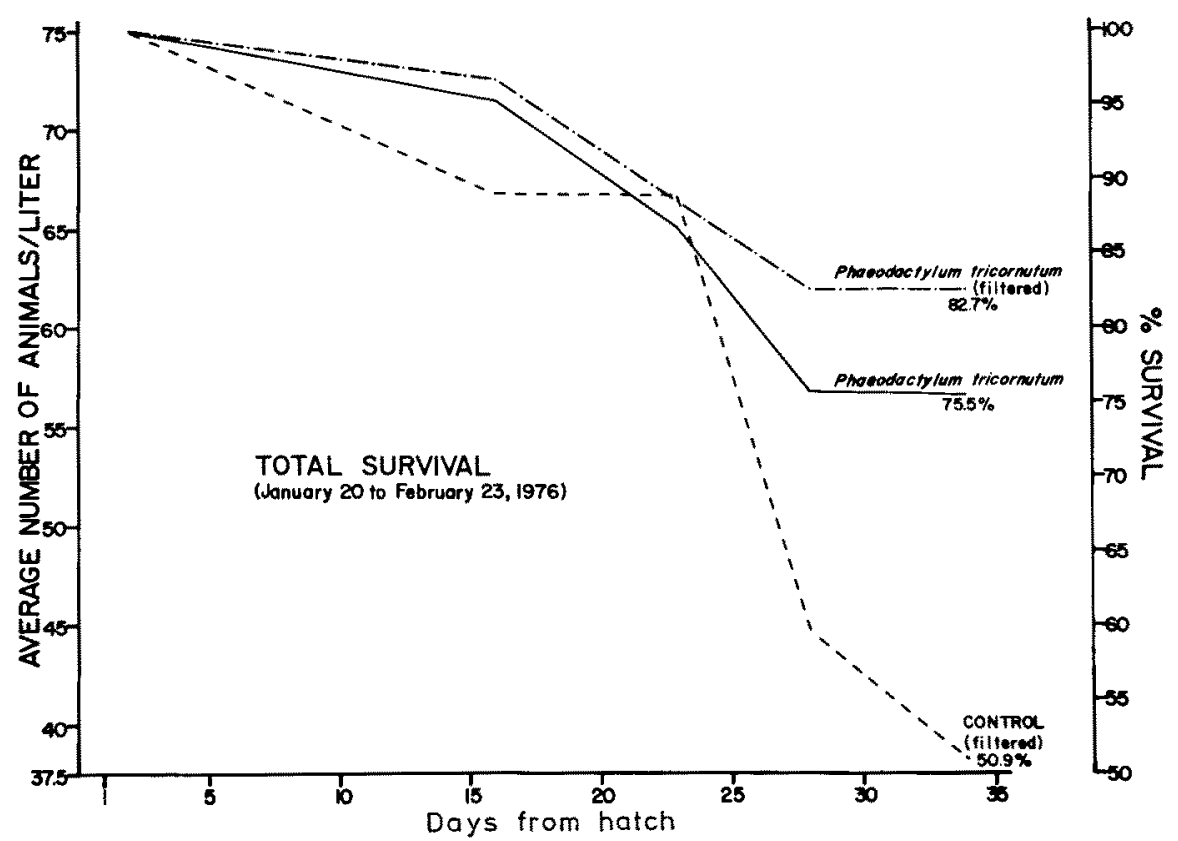

Fig. 3: Average number of animals per liter and percent survival of Macrobrachium rosenbergii in two algal and one control treatments 
in each replicate. Total survival indicates a relatively constant mortality in all treatments (Fig. 3). Counts at day 16 indicated slightly higher survival in the algal treatments but all treatments averaged above $90 \%$ survival. By day 23 all treatments showed very similar mean survival, $86-89 \%$. Subsequently, survival in the control cultures, $73 \%(55 / 1)$ in the static algal supplement cultures, and $41 \%(32 / 1)$ in the control treatment survival $(50.9 \%)$ was appreciably lower than survival in either the static algal supplemented treatment $(75.5 \%)$ or the recirculated algal supplemented treatment $(82.7 \%$ ). Total percent survival in each replicate was analyzed by single classification analysis of variance (ANOVA) after normalizing the percentage data by angular transformation and testing for homoscedasticity with the $F_{\text {max }}$-test (SoKAL \& Rohlf, 1969). Appropriate a priori comparisons were selected and results of the complete ANOVA are presented in Table 1. Overall treatment variance was significant $(\alpha=0.05)$ indicating real differences in survival among treatments. When total

Table 1

Total survival data (28 days) analysed by single classification ANOVA with selected a priori comparisons

\begin{tabular}{|lcrrr|}
\hline Source & d.f. & SS & MS & F \\
\hline Treatments & 2 & 661.10 & 330.55 & \multicolumn{1}{c|}{$7.14^{*}$} \\
Algae versus control & 1 & 636.78 & 636.78 & $13.76^{* * *}$ \\
Among algae & 1 & 24.32 & 24.32 & 0.52 n.s. \\
Error & 6 & 277.59 & 46.24 & \\
Total & 8 & 938.69 & & \\
\hline
\end{tabular}

treatment variance was partitioned into algal versus control treatments and among algal treatments it became apparent that overall variance was supported only by differences $(\alpha=0.01)$ between the algal and control treatments. There appeared to be no significant difference between the algal treatments.

Postlarval production was compared through evaluation of larval and postlarval dynamics (Fig. 4). Postlarvae appeared first in the algal supplemented cultures, and by day 23 approximately $18 \%$ of the larvae in the algal supplemented treatments had metamorphosed. The control had less than $2 \%$ on the same day. Postlarval production peaked in the algal supplemented cultures by day 28 averaging approximately $65 \%$ of the stocking density to postlarvae ( $\sim 48$ postlarvae/l). Control cultures averaged less than $23 \%$ to postlarvae $(\sim 16$ postlarvae/l) on the same date. Final postlarval production averaged approximately $78 \%(59 / 1)$ in the recirculating algal supplement cultures, $73 \%(55 / 1)$ in the static algal supplement cultures, and $41 \%(32 / 1)$ in the control cultures. Postlarval production was also analyzed by single classification ANOVA. The percentage of postlarvae produced by each replicate of each treatment was normalized by the angular transformation and the variances of the transformed treatments were tested for homogeneity of variance. Overall treatment variance was significant at the $95 \%$ level (Table 2 ) but was supported only by differences between algal and control treatment $(\alpha=0.01)$. Thus, postlarval production, like survival, was significantly different only in comparisons between algal treatments and controls - 


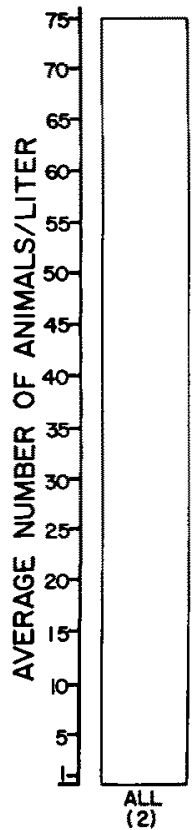

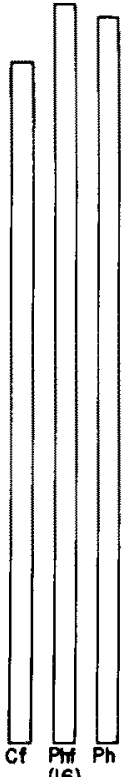

(16)

\section{LARVAL and POSTLARVAL DYNAMICS (January 20 to Fobruary 23, 1976) CF CONTROL (filtered) Phf Phasodactyfum tricornutum (filtered)}

Ph Phasodoctylum tricornufum
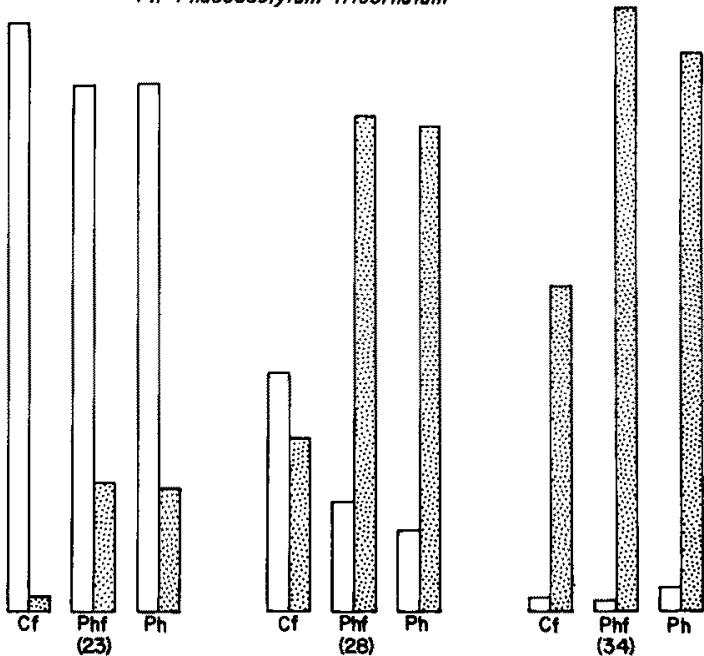

Fig. 4: Average survival per liter of Macrobrachium rosenbergii larvae (clear) and generation of postlarvae per liter (shaded) in two algal and one control treatments. Numbers in parenthesis indicate days from hatch

there were no significant differences in either postlarval production or survival between static and recirculating algal supplemented cultures.

Comparisons between the above results and those reported in the literature produce several salient points. First, larval development, survival, and postlarval production are similar to results previously reported (MADDOx \& MANzI, in press) for static cultures - this applies to controls as well as algal treatments. Second, total survival and postlarval production in actual numbers of animals $/ 1$ are the highest reported. At a stocking density of 75 larvae/l our results showed total survival and postlarval production of 62 and 59 animals/1 respectively for recirculating algal supplemented cultures, 57 and 55 animals $/ 1$, respectively for static algal supplemented cultures, and 38 and 32 animals/1, respectively for the controls. Fujmura \& Okamoto (1972)

Table 2

Postlarvae production (28 days) analysed by single classification ANOVA with selected a priori comparisons

\begin{tabular}{|cccrc|}
\hline Source & d.f. & \multicolumn{1}{c}{ SS } & \multicolumn{1}{c|}{ MS } & \multicolumn{1}{c|}{ F } \\
\hline Treatments & 2 & 1276.16 & 638.08 & $6.80^{*}$ \\
Algae versus control & 1 & 1276.12 & 1276.12 & $13.60^{* *}$ \\
Among algae & 1 & 0.04 & 0.04 & 0.00 n.s. \\
Error & 6 & 562.81 & 93.80 & \\
Total & 8 & 1838.98 & & \\
\hline
\end{tabular}


reported estimates of survival and postlarval production at 11.0 to 15.0 animals $/$, WICKINS (1972) at 10.5 to 12.4 animal/1, and SANDIFER (in press) at 25 to 32 animals/1. At a stocking density of 50 larvae/1, MADDox \& MANZI (in press) reported total survival of from 37 to 45 animals $/ 1$ in static algal cultures. In the above comparisons the only other authors using both algal supplements and similar stocking densities were Fujimura \& Окамото (1972). Finally, larval growth and development proceeded at a rate somewhat more rapid than normally reported. Cultures supplemented with $P$. tricornutum exhibited stage 10 (LSI) by day 18 and both static and recirculating algal supplemented cultures showed greatest postlarval production by day 28. This is five to seven days earlier than previously reported (Fujumura, 1966; Fujmura \& Oxamoto, 1972).

Results of water quality monitored over the first nine days consistently showed higher levels of ammonia in static algal supplemented treatments (to $4.0 \mathrm{mg} / \mathrm{l}$ ) than in recirculated algal supplemented treatments (to $2.0 \mathrm{mg} / \mathrm{l}$ ) and controls (to $1.2 \mathrm{mg} / \mathrm{l}$ ). Nitrite and nitrate levels remained highest in the recirculated algal treatment $(2.15$ and $>70.4 \mathrm{mg} / 1$, respectively) than in either the static $(0.99$ and $19.8 \mathrm{mg} / 1)$ or control $(1.82$ and $66.0 \mathrm{mg} / \mathrm{l})$ treatments. Between days 16 and 23 of the culture (after initiating fish egg supplements) ammonia levels increased in all treatments with a high of $5.85 \mathrm{mg} / \mathrm{l}$ in the static treatment and $2.60 \mathrm{mg} / \mathrm{l}$ in both the algal supplemented and control recirculating treatments. These results indicated, as did previous experiments (MADDOX \& MANZI, in press), that the water quality parameters measured have little if any relationship to the enhancement of $M$. rosenbergii larval culture by algal supplements.

\section{SUMMARY}

1. A comparative study of algal supplement (Phaeodactylum tricornutum) enhancement of static and recirculating Macrobrachium rosenbergii larval culture was conducted.

2. Algal supplements significantly increased larval survival in both static and recirculating culture systems.

3. Algal supplements significantly increased postlarval production in both static and recirculating culture systems.

4. There was no significant difference in either survival or postlarval production between algal supplemented static and recirculating culture systems.

5. The rate of larval development was appreciably increased by the additions of an algal supplement.

6. The chemical parameters of water quality monitored $\left(\mathrm{NH}_{4}, \mathrm{NO}_{2}, \mathrm{NO}_{3}\right)$ did noch appear to be related to the algal supplement enhancement of $M$. rosenbergii larval culture.

Acknowledgements. We thank F. L. Forsom, J. E. Williams, M. Y. Bobo and W. Z. Carson for assistance in the laboratory. We also thank J. S. Hopkins for his culture expertise, M. A. BARWICK for preparation of the typescript and K. R. SWANsON for preparing the figures and assisting in the project. We would like to express our gratitude to the entire mariculture project staff for providing facilities and equipment, particularly Drs. P. A. SANDTFER and T. I. J. SMITH for suggesting the research and reviewing the manuscript. 


\section{LITERATURE CITED}

Dupuy, J. L., 1973. Translation of mariculture research into a commercial oyster seed hatchery. Proc. a. Conf. Mar. Technol, Soc. 9, 677-685.

Fujmura, T., 1966. Notes on the development of a practical mass culturing technique for the giant prawn Macrobrachium rosenbergii. Proc. Indo-Pacif. Fish. Coun. 12th Ses., Honolulu, Hawaii. IPFC/C66/WP47, 4 pp.

- 1974. Development of a prawn culture industry in Hawaii. Hawaii sub-project no. H-14-D, Job completion rep. U. S. Dept, of Commerce, NOAA, NMFS, 28 pp.

- \& OkAmoto, H., 1972. Notes on progress made in developing a mass culturing technique for Macrobracbium rosenbergii in Hawaii. In: Coastal aquaculture in the Indo-Pacific region. Ed. by T. V. R. Pillay. Fishing News Books, London, 313-327.

LrNG, S. W., 1962. Studies on the rearing of larvae and juveniles and culturing of adults of Macrobrachium rosenbergii (DE MAN). Tech. Pap. Indo-Pacif. Fish. Coun. 57, 1-15.

- 1969a. The general biology an development of Macrobrachium rosenbergii (DE MAN). F.A.O. Fish. Rep. 57 (3), 589-606.

- 1969b. Methods of rearing and culturing Macrobrachium rosenbergii. F.A.O. Fish. Rep. 57 (3), 607-619.

Maddox, M. B. \& ManzI, J. J., 1976. The effect of algal supplements on static system culture of Macrobrachium rosenbergii (DE MAN) larvae. Proc. a. Workshop World Maricult. Soc., 7 (in press).

Persoone, G. \& Sorgeloos, P., 1974. Technological improvements for the cultivation of invertebrates as food for fishes and crustaceans. 2. Hatching and culturing of the brine shrimp Artemia salina L. Ms., State Univ. Ghent, 23 pp.

- - 1975. Technological improvements for the cultivation of invertebrates as food for fishes and crustaceans. 1. Devices and methods. Aquaculture 6, 275-289.

Sandregr, P. A. \& Smrth, T. I. J., 1974. Development of a crustacean mariculture program at South Carolina's Marine Resources Research Institute. Proc. a. Workshop World Maricult. Soc. $5,431-438$.

- - 1976. Experimental aquaculture of the Malaysian prawn, Macrobrachitum rosenbergii (DE MAN), in South Carolina (U.S.A.). Proc. F.A.O. Tech. Conf. Aquacult. (In press).

Smith, T. I. J., Sandifer, P. A. \& Trimble, W. C., 1974. Progress in developing a recirculating synthetic seawater hatchery for rearing larvae of Macrobrtchium rosenbergii. Proc. FoodDrugs from the Sea Conf., 4 (in press).

Sokal, R. R. \& Rohlf, F. J., 1969. Biometry. The principles and practice of statistics in biological research. Freeman, San Francisco, 776 pp.

Sorgezoos, P., 1973. The influence of light and dissolved oxygen on the reproduction of the brine shrimp, Artemia salina. 8th European Symp. Mar. Biol., 12 pp. (Unpubl.)

SRNA, R. F., 1975. Nitrification: Effect of environmental factors. Seascope $\mathbf{5}$.

UNO, Y. \& KWON CHIN soo, 1969. Larval development of Macrobracbium rosenbergii (DE Man) reared in the laboratory. J. Tokyo Univ. Fish. 55, 179-190.

Wickins, J. F., 1972. Experiments on the culture of the spot prawn, Pandalus platycerus BRANDT, and the giant freshwater prawn, Macrobracbium rosenbergii (DE MAN). Fishery Invest. (Ser. 2) 27, 1-23.

- \& BEARD, T. W., 1973. Observations on the breeding and growth of the giant freshwater prawn, Macrobrachium rosenbergii (DE MAN), in the laboratory. Aquaculture 3, 159-174.

First author's address: Dr. J. J. Manzi

Marine Resources Research Institute

P. O. Box 12559

Charleston, South Carolina 29412

USA 